\title{
Hubungan Mekanisme Koping Dengan Skor Kecemasan Dalam Menghadapi Ujian Keterampilan Medik Pada Mahasiswa Prodi Pendidikan Dokter Universitas Mataram
}

\author{
Nurrahmasia $^{1 *}$, Emmy Amalia $^{1}$, Dian Puspita Sari ${ }^{1}$ \\ 1.Program Studi Pendidikan Dokter Fakultas Kedokteran Universitas Mataram \\ Korespondensi : nurrahmasia123@gmail.com
}

\begin{abstract}
ABSTRAK
Pendahuluan: Kecemasan merupakan suatu gejala yang timbul dari konflik bawah sadar yang tidak terselesaikan. Kecemasan ujian merupakan kecemasan antisipatif yang timbul ketika menghadapi situasi ujian. Setiap individu memiliki cara ataupun mekanisme koping yang berbeda dalam menghadapi masalahnya. Penggunaan mekanisme koping yang sesuai membantu seseorang beradaptasi terhadap perubahan atau beban yang dihadapi, termasuk beban belajar menghadapi ujian. Penelitian ini meneliti hubungan antara mekanisme koping dengan skor kecemasan mahasiswa program studi pendidikan dokter dalam menghadapi ujian keterampilan medik, serta korelasi antara skor kecemasan dengan nilai ujian.

Metode: Penelitian ini menggunakan desain cross-sectional. Responden penelitian ini adalah mahasiswa program studi pendidikan dokter Fakultas Kedokteran Universitas Mataram tahun pertama dan kedua. Data mekanisme koping diambil dengan menggunakan instrumen Brief COPE, sementara data kecemasan diambil menggunakan instrumen PTA (Performance Test Anxiety). Keduanya telah diterjemahkan ke Bahasa Indonesia dan diuji validitas dan reliabilitasnya. Uji statistik yang digunakan adalah uji Mann-Whitney dan uji Spearman.

Hasil: Sebanyak 207 mahasiswa berpartisipasi dalam penelitian ini. Skor kecemasan mahasiswa didapatkan 70.00 (31-94) dan 83.1\% menggunakan problem focused coping. Penggunaan problem-focused coping berhubungan signifikan dengan skor kecemasan yang lebih rendah $(\mathrm{p}=0,032)$. Tidak terdapat hubungan antara skor kecemasan dengan hasil ujian keterampilan medik pada mahasiswa tahun pertama maupun kedua $(p>0.05)$

Kesimpulan: Jenis mekanisme koping yang paling banyak digunakan oleh mahasiswa fakultas kedokteran universitas mataram adalah problem focused coping dan jenis mekanisme koping ini berhubungan dengan skor kecemasan ujian yang lebih rendah.
\end{abstract}

Kata Kunci: kecemasan ujian; mekanisme koping; keterampilan medik.

\section{ABSTRACT}

Introduction: Anxiety is a symptom that arises from unfinished subconscious conflicts. Exam anxiety is anticipatory anxiety experienced when student in an examination situation. Each individual has a different coping mechanism in dealing with the problem.The use of appropriate coping mechanism helps individuals adapt to the changes or burden they face, including studying for exams. This study examined the relationship between coping mechanisms and anxiety score of medical students in facing clinical skills exam, as well as the correlation between anxiety score and clinical skills exam score.

Methods:This study used a cross-sectional design. The study subjects were first and second year medical students at the Faculty of Medicine, Universitas Mataram. Coping mechanism data were obtained using the Brief COPE Inventory, while anxiety data were obtained using the Performance Test Anxiety (PTA). Both questionnaires have been 
translated into Bahasa Indonesia andtested for validity and reliability. The statistical test used in this study were the Mann-Whitney test and the Spearman test.

Results: A total of 207 students participated in this study. The participants' anxiety score was 70.00 (31-94)and $83.1 \%$ using problem focused coping. The use of problem focused coping was significantly associated with lower anxiety score $(p=0.032)$. There was no relationship between anxiety score and clinical skills examination results for the first and second year student $(p>0.05)$.

Conclusion: The use of problem focused coping was prevalent among the first and second year students participated in this study and this coping mechanism was associated with lower exam anxiety score.

Keyword: exam anxiety; coping mechanism; medical skill exam.

\section{PENDAHULUAN}

Kecemasan merupakan suatu gejala yang timbul dari konflik bawah sadar yang tidak terselesaikan ${ }^{1}$. Rasa cemas dapat muncul sebagai akibat dari kondisi stres atau konflik, yang biasanya terjadi saat individu menghadapi suatu perubahan situasi dalam hidupnya dan dituntut untuk mampu beradaptasi. Kecemasan merupakan gejala yang normal pada manusia, namun menjadi patologis bila gejalanya menetap dan mengganggu aktivitas serta kenyamanan individu ${ }^{2}$.

Kecemasan dapat memengaruhi pikiran, perilaku dan kondisi tubuh. Pengaruh kecemasan terhadap pikiran misalnya terkait persepsi individu terhadap dirinya sendiri, sedangkan terhadap perilaku, kecemasan mendorong individu menghindari penyebab kecemasan atau berusaha untuk meminimalkan kecemasan ${ }^{3}$. Pada kondisi cemas, tubuh cenderung memberikan respon berlebihan, sebagai contoh, meningkatnya detak jantung dan frekuesnsi napas, bahkan sampai merasa sesak napas. Selain itu manifestasi fisiologis kecemasan lainnya termasuk peningkatan sekresi keringat, pusing, mual, hingga panik ${ }^{4}$.

Kecemasan dapat dirasakan oleh setiap orang dan dapat muncul saat kita menghadapi suatu peristiwa penting seperti ujian atau wawancara kerja $^{3}$. Kecemasan ujian juga dapat disebut sebagai kecemasan antisipatif. Adanya ketidaknyamanan fisiologis yang menyebabkan rangsangan berlebihan, ketegangan, gejala somatik hingga psikologis sehingga individu menjadi tidak fokus, mengalami kemunduran dalam persepsi dan kelancaran berpikir, yang dapat menyebabkan kekhawatiran dan ketakutan akan kegagalan, baik itu sebelum atau saat menghadapi ujian 5 .

Data secara global menemukan bahwa prevalensi mahasiswa kedokteran yang mengalami kecemasan sebesar 29,2\% hingga $38,7 \%$. Tingkat kecemasan tersebut tergolong tinggi dibandingkan dengan populasi pada umumnya. Hal tersebut dapat diakibatkan oleh berbagai faktor seperti ciri kepribadian mahasiswa yang cenderung perfeksionis, ambisius dan juga berkaitan dengan beban akademik maupun keuangan serta kurangnya waktu tidur ${ }^{6}$. Kecemasan berkaitan erat dengan keadaan mental yang juga akan berpengaruh terhadap prestasi belajar. Mahasiswa yang mengalami masalah psikologis seperti kecemasan dapat mengganggu prestasi belajarnya dan hal ini dapat dilihat dari hasil ujiannya ${ }^{7}$.

Ujian praktik keterampilan medik di Program Studi Pendidikan Dokter Fakultas Kedokteran Universitas Mataram (PSPD FK UNRAM) dilaksanakan setiap akhir periode kegiatan pembelajaran yang berdurasi lima minggu. Ujian ini menggunakan metode Objective Structured Clinical Examination (OSCE) yang mengharuskan peserta ujian berpindah dari satu stasiun ke stasiun lainnya 
pada waktu yang telah ditentukan. Pada setiap stasiun peserta akan diberi suatu skenario klinis dan harus menunjukkan kemampuan keterampilan klinis tertentu dalam durasi waktu yang diberikan ${ }^{8}$. Performa peserta akan dievaluasi secara independen oleh seorang penguji di stasiun tersebut menggunakan daftar tilik (checklist) yang terstandar. Dengan demikian, setiap peserta ujian akan melalui tes yang sama, dan dinilai oleh penguji yang sama dengan instrumen penilaian yang sama ${ }^{9}$. Ujian keterampilan medik di PSPD FK UNRAM umumnya hanya mengujikan dua sampai tiga keterampilan saja dalam satu kali ujian. Pada penelitian ini mahasiswa tahun pertama mengikuti dua komponen keterampilan klinik yaitu Komunikasi Interpersonal dan Hand Hygiene, sedangkan pada mahasiswa tahun kedua mengikuti komponen keterampilan klinik Refleks Patologi dan Penyuluhan. Metode OSCE ini diketahui menimbulkan kecemasan lebih tinggi dibandingkan jenis ujian lainnya ${ }^{10}$.

Kecemasan yang timbul pada saat ujian keterampilan medik diperkirakan dapat mengganggu konsentrasi dan kemampuan dalam berpikir dan bertindak saat ujian, sehingga akan sangat berpengaruh terhadap hasil yang dicapai pada ujian tersebut. Kecemasan akan bertambah dengan suasana ujian yang hening, menegangkan, serta dosen penguji yang selalu memantau saat ujian berlangsung. Ketakutan akan ketidakmampuan juga menimbulkan kecemasan bagi mahasiswa ${ }^{11}$. Keadaan penuh tekanan tersebut dapat dialami oleh mahasiswa yang baru pertama kali menghadapi ujian keterampilan medik maupun yang sudah berkali-kali menghadapinya ${ }^{12}$. Kecemasan dapat memengaruhi hasil yang akan diperoleh mahasiswa terutama pada kecemasan tingkat sedang hingga panik ${ }^{13}$.

Setiap individu memiliki cara ataupun strategi koping yang berbeda dalam menghadapi masalahnya ${ }^{14}$. Mekanisme koping merupakan upaya untuk menyelesaikan masalah dan mekanisme pertahanan yang digunakan untuk melindungi diri, mekanisme untuk mengatasi perubahan atau beban dan beban tersebut menimbulkan respon dalam diri. Apabila mekanisme koping ini berhasil maka individu akan dapat beradaptasi terhadap perubahan atau beban tersebut ${ }^{15,16}$.

Mahasiswa dapat menggunakan berbagai mekanisme koping untuk mengolah stres yang dihadapi. Hal tersebut melibatkan strategi pemecahan masalah, ekspresi emosi dan adaptasi terhadap masalah sehingga dapat mengurangi kecemasan yang dapat berpengaruh pada kesehatan mental maupun fisik mahasiswa ${ }^{18}$.

Mekanisme koping dibedakan menjadi dua tipe menurut Lazarus \& Folkman yaitu mekanisme koping berfokus pada masalah (problem-focused coping) dan mekanisme koping berfokus pada emosi (emotional-focused coping). Problem-focused coping merupakan usaha untuk memperbaiki suatu situasi dengan membuat perubahan atau mengambil beberapa tindakan dan usaha segera untuk mengatasi ancaman. Problemfocused coping berorientasi untuk mencari pokok permasalahan dan berusaha untuk memecahkannya. Sedangkan emotionalfocused coping dapat diartikan sebagai usahausaha dan gagasan yang mengurangi distress emosional. Mekanisme koping berfokus pada emosi tidak memperbaiki situasi tetapi seseorang sering merasa lebih baik. Koping yang berfokus pada emosi mencakup semua upaya regulatif untuk mengurangi konsekuensi emosional dari peristiwa yang menimbulkan stres ${ }^{17}$.

Ujian OSCE merupakan salah satu stressor yang dapat memicu timbulnya kecemasan, sehingga mahasiswa diharapkan dapat memilih mekanisme koping yang tepat agar dapat beradaptasi terhadap permasalahan atau beban tersebut. Berdasarkan permasalahan tersebut dan pertimbangan 
bahwa penelitian seperti ini belum pernah dilakukan di Universitas Mataram maka dirasa perlu untuk meneliti hubungan mekanisme koping dengan skor kecemasan dalam menghadapi ujian keterampilan medik, serta korelasi antara skor kecemasan dengan nilai ujian mahasiswa PSPD FK UNRAM. Penelitian ini hanya akan berfokus pada kecemasan ujian, bukan kecemasan pada umumnya.

\section{METODE}

Penelitian ini adalah suatu penelitian cross-sectional pada mahasiswa kedokteran tahap akademik (preklinik/tahap sarjana). Pada tahap ini, di setiap semester mahasiswa akan menjalani tiga blok yang berjalan paralel dengan mata kuliah keterampilan medik, yang masing-masing berdurasi lima minggu. Pada setiap mata kuliah keterampilan medik, mahasiswa mempelajari dua hingga tiga keterampilan. Ujian keterampilan medik dilaksanakan setiap akhir periode pembelajaran yang berdurasi lima minggu dan masing-masing keterampilan diuji pada satu stasiun. Dengan demikian, terdapat dua hingga tiga stasiun setiap kali pelaksanaan ujian OSCE. Terkait pertanyaan penelitian pertama, yaitu hubungan mekanisme koping dengan kecemasan ujian, variabel yang diteliti adalah mekanisme koping sebagai variabel prediktor dan kecemasan ujian sebagai variabel kriterion. Sementara pada pertanyaan penelitian kedua, yaitu hubungan kecemasan ujian dengan nilai ujian keterampilan medik, kecemasan ujian berlaku sebagai variabel prediktor sementara nilai ujian berlaku sebagai variabel kriterion.

Populasi penelitian ini adalah mahasiswa PSPD FK UNRAM tahun pertama dan kedua di tahun ajar 2020 - 2021 dengan total mahasiswa 237 orang. Kriteria inklusi penelitian adalah mahasiswa yang mengikuti keterampilan medik komunikasi interpersonal (ujian IA) dan hand hygiene (ujian IB) di semester pertama (angkatan 2020), atau yang mengikuti keterampilan medik pemeriksaan refleks patologis (ujian IIA), dan penyuluhan (ujian IIB) di semester ketiga (angkatan 2019), serta bersedia menjadi partisipan penelitian. Mahasiswa akan dieksklusi sebagai subjek penelitian apabila tidak memenuhi persyaratan mengikuti ujian keterampilan medik yang disebutkan di atas, atau sedang mengalami gangguan psikatri, dalam pengobatan oleh psikiater, atau mengonsumsi obat-obatan psikofarmaka. Penelitian ini dilaksanakan pada bulan Oktober - Desember 2020.

Pengumpulan data mekanisme koping dilakukan menggunakan kuesioner The Brief COPE Inventory, sementara kecemasan diukur menggunakan kuesioner Performance Test Anxiety. Kedua kuesioner ini aslinya berbahasa Inggris dan telah melalui proses penerjemahan dengan metode Brislin, metode back translation dari Brislin. Proses penerjemahan dengan metode ini melibatkan dua tahap penerjemahan. Pada tahap pertama, kuesioner diterjemahkan dari bahasa Inggris ke bahasa bahasa Indonesia. Selanjutnya pada tahap kedua, kuesioner yang telah diterjemahkan di tahap pertama diterjemahkan kembali ke Bahasa Inggris (backward translation) oleh penerjemah yang berbeda. Kedua hasil terjemahan lalu dibandingkan untuk menilai kesamaan konsepnya ${ }^{19}$. Setelah diterjemahkan, peneliti melakukan uji keterbacaan pada 20 orang mahasiswa untuk menilai kejelasan butir-butir dalam instrumen, dan uji validitas dan reliabilitas pada 95 orang mahasiswa tahun ketiga. Subjek yang dilibatkan dalam uji keterbacaan dan uji validitas dan reliabilitas adalah subjek yang berbeda dengan responden penelitian.

\section{The Brief COPE Inventory} dikembangkan oleh Carver terdiri dari 28 butir pernyataan yang mewakili tiga mekanisme koping: Problem-focused coping, Emotional-focused coping dan Avoidantfocused coping ${ }^{20}$. Responden menjawab setiap 
item dalam kuesioner dengan empat pilihan jawaban, yaitu $1=$ belum pernah, 2 = kadangkadang, $3=$ sering, dan $4=$ sangat sering. Pengelompokan dilakukan dengan menghitung skor relatif yang diperoleh dari perhitungan skor total pada setiap subskala dibagi dengan skor maksimal pada subskala tersebut. Skor yang paling besar dari ketiga subskala ini akan menjadi jenis mekanisme koping yang dominan digunakan oleh responden ${ }^{21,22}$. Seluruh butir pernyataan yang mewakili problem-focused dan emotionalfocused coping memiliki validitas yang baik (nilai Corrected Item-Total Correlation >0.3) dan juga reliabilitas yang baik (koefisien Cronbach's alpha masing-masing 0.688 dan 0.751), namun dua dari delapan butir pernyataan dalam The Brief COPE Inventory yang mewakili avoidant focused coping tidak menunjukkan validitas yang baik pada dua kali pengujian (corrected item-total correlation < 0.3) sehingga tidak dimasukkan dalam analisis data. Koefisien Cronbach's alpha untuk subskala avoidant-focused coping adalah 0.608 .

Kuesioner Performance Test Anxiety terdiri dari 19 butir pernyataan yang mewakili dua dimensi kecemasan ujian, yaitu kecemasan kognitif (11 butir) dan kecemasan fisiologis (8 butir). Pernyataan dalam kuesioner ini direspon dengan memilih satu dari lima skala yang menunjukkan persetujuan ( 1 = sangat tidak setuju dan $5=$ sangat setuju). Skor dari seluruh item kemudian dijumlahkan. Semakin tinggi skor PTA menunjukkan tingkat kecemasan performa yang semakin tinggi pula. Sepuluh dari 11 butir pernyataan pada subskala kecemasan kognitif menunjukkan validitas yang baik, dan kedelapan butir pernyataan pada subskala kecemasan fisiologis menunjukkan validitas yang baik (Corrected Item-Total Correlation $>0.3$ ). Kedua subskala pada kuesioner PTA ini juga menunjukkan reliabilitas yang baik dengan nilai koefisien Cronbach's alpha masing masing 0.908 dan 0.876 .
Kedua kuesioner di atas diedarkan melalui tautan Google Form. Pengambilan data mekanisme koping dengan kuesioner The Brief COPE Inventory dilakukan pada awal periode pembelajaran di bulan Oktober, sedangkan pengambilan data kecemasan dengan kuesioner Performance Test Anxiety dilakukan pada sore / malam hari sebelum ujian keterampilan medik tanggal 13 Oktober 2020 untuk mahasiswa tahun pertama, dan tanggal 20 oktober 2020 untuk mahasiswa tahun kedua. Pengambilan data mekanisme koping dilakukan beberapa minggu lebih awal dari pengambilan data skor kecemasan karena dua alasan. Pertama, untuk mengetahui mekanisme koping yang biasa digunakan responden pada situasi-situasi lain sebelum konteks ujian OSCE dalam penelitian ini. Pertimbangan lainnya adalah untuk mencegah bias pada jawaban responden karena mahasiswa tahun pertama akan mendapatkan kuliah manajemen stres dan mekanisme koping pada blok yang sedang berjalan, karenanya pengambilan data mekanisme koping dilakukan sebelum kuliah tersebut. Sebelum melakukan pengambilan data, peneliti menyampaikan informasi mengenai penelitian secara lisan melalui video conference sebelum partisipan mengikuti kegiatan pembelajaran daring. Informasi penelitian juga disampaikan secara tertulis di awal kuesioner sehingga responden dapat memahami maksud dan tujuan penelitian ini. Selanjutnya sebelum mengisi kuesioner, partisipan juga dimintai persetujuannya mengikuti penelitian ini. Untuk mengetahui ada atau tidaknya mahasiswa yang sedang mengalami gangguan psikiatri dan atau mengonsumsi obat-obatan psikofarmaka, peneliti melampirkan pertanyaan pada kuesioner yang diedarkan. Apabila responden menjawab tidak sedang mengalami hal-hal tersebut, maka responden akan langsung diarahkan untuk mengisi kuesioner yang telah disediakan. 
Data nilai ujian keterampilan medik merupakan data sekunder yang didapatkan dari Laboratorium Keterampilan Medik Fakultas Kedokteran Universitas Mataram. Analisis data pada penelitian ini dilakukan menggunakan aplikasi SPSS versi 25. Analisis diawali dengan uji statistik deskriptif dilanjutkan dengan uji hipotesis dengan analisis bivariat menggunakan uji MannWhitney dan uji Spearman.

\section{HASIL}

Sebanyak 207 mahasiswa berpartisipasi dalam penelitian ini. Mahasiswa tahun pertama berjumlah 113 orang (54.6\%) dan tahun kedua berjumlah 94 orang (46.4\%). Sebagian besar responden berjenis kelamin perempuan $(72.9 \%)$, dan berusia 17 hingga 21 tahun dengan rerata $18.59( \pm 0.78)$. Gambaran umum responden penelitian dapat dilihat pada tabel 1 .

\begin{tabular}{|c|c|c|}
\hline Karakteristik & $\mathrm{N}$ & $(\%)$ \\
\hline Total & 207 & $(100)$ \\
\hline \multicolumn{3}{|l|}{ Tahun Studi } \\
\hline I & 113 & $(54,6)$ \\
\hline II & 94 & $(45,4)$ \\
\hline \multicolumn{3}{|l|}{ Jenis Kelamin } \\
\hline laki-laki & 56 & $(27.1)$ \\
\hline perempuan & 151 & (72.9) \\
\hline \multicolumn{3}{|l|}{ Usia } \\
\hline 17 tahun & 12 & $(5.8)$ \\
\hline 18 tahun & 84 & $(40.6)$ \\
\hline 19 tahun & 87 & $(42.0)$ \\
\hline 20 tahun & 23 & (11.1) \\
\hline 21 tahun & 1 & $(0.5)$ \\
\hline
\end{tabular}

Pada penelitian ini didapatkan median skor kecemasan pada responden adalah 70.00 dari skor maksimal 94.00. Responden perempuan menunjukkan median skor kecemasan lebih tinggi dibandingkan laki-laki (73.00 vs 68.50) dan didapatkan perbedaan skor kecemasan yang signifikan antara kedua jenis kelamin $(\mathrm{p}=0.003)$. Median skor kecemasan responden tahun kedua sedikit lebih rendah dibanding tahun pertama (71.00 vs 69.00$)$, meski demikian perbedaan ini tidak signifikan secara statistik $(\mathrm{p}=0.309)$. Gambaran skor kecemasan ditunjukkan pada tabel 2.

Tabel 2. Gambaran Skor Kecemasan Responden Penelitian

\begin{tabular}{lccc}
\hline & $\mathrm{N}$ & $\begin{array}{c}\text { Median skor } \\
\text { kecemasan } \\
\text { (min-maks) }\end{array}$ & $\mathrm{P}$ \\
\hline $\begin{array}{l}\text { Total } \\
\text { Jenis }\end{array}$ & 207 & $70.00(31-94)$ & \\
kelamin & & & \\
$\quad$ Laki-laki & 56 & $68.50(31-82)$ & 0.003 \\
$\quad$ Perempuan & 151 & $73.00(41-94)$ & \\
$\begin{array}{l}\text { Tahun } \\
\text { studi }\end{array}$ & & & \\
I & 113 & $71.00(31-94)$ & 0.309 \\
II & 94 & $69.00(44-93)$ & \\
\hline
\end{tabular}

Tabel 3. Gambaran Profil Mekanisme Koping Responden Penelitian

\begin{tabular}{lcc}
\hline & $\begin{array}{c}\text { Problem } \\
\text { Focused } \\
\text { Coping } \\
\text { N }(\%)\end{array}$ & $\begin{array}{c}\text { Emotion } \\
\text { Focused } \\
\text { Coping } \\
\text { N }(\%)\end{array}$ \\
\hline $\begin{array}{l}\text { Mekanisme } \\
\text { Koping }\end{array}$ & $172(83.1)$ & $35(16.9)$ \\
Berdasarkan & & \\
Jenis Kelamin & & \\
$\quad$ & & \\
$\quad$ Laki-laki & $44(78,6)$ & $12(21,4)$ \\
$\quad$ Perempuan & $128(84,8)$ & $23(15,2)$ \\
Berdasarkan & & \\
Tahun Studi & & \\
$\quad$ I & $101(89,4)$ & $12(10,6)$ \\
$\quad$ II & $71(75,5)$ & $23(24,5)$ \\
\hline
\end{tabular}

Sebagian besar responden penelitian ini dominan menggunakan mekanisme koping problem-focused coping dibandingkan emotion-focused coping (172 vs 35 orang). Tidak ada satupun yang ditemukan menggunakan avoidant coping sebagai mekanisme koping dominan. Baik responden perempuan maupun laki-laki, keduanya lebih banyak memilih problem-focused coping 
dibandingkan emotion-focused coping. Sama halnya, responden pada kedua tahun studi yang berbeda juga lebih dominan menggunakan problem-focused coping dibandingkan emotion-focused coping (Tabel $3)$.

Rerata nilai ujian keterampilan medik tahun pertama untuk ujian I A dan I B hampir sama (90.27 vs 94.21). Sedangkan untuk rerata nilai ujian keterampilan medik tahun kedua untuk ujian II A dan II B juga tidak menunjukkan nilai yang jauh berbeda ( 88.77 vs 89.06). Akan tetapi rerata nilai ujian keterampilan medik tahun pertama cenderung lebih tinggi dibandingkan dengan tahun kedua (Tabel 4).

Tabel 4. Gambaran Hasil Ujian Hasil Ujian Keterampilan Medik

\begin{tabular}{|c|c|c|}
\hline & Mean $( \pm \mathrm{SD})$ & $\begin{array}{l}\text { Median (min- } \\
\text { maks) }\end{array}$ \\
\hline \multicolumn{3}{|c|}{ Hasil Ujian Tahun I (N=113) } \\
\hline I A & $90.27( \pm 5.94)$ & $\begin{array}{l}89.43 \\
(75.29-100)\end{array}$ \\
\hline I B & $94.21( \pm 4.52)$ & $\begin{array}{l}93.880 \\
(74.23-100)\end{array}$ \\
\hline \multicolumn{3}{|c|}{ Hasil Ujian Tahun II (N=94) } \\
\hline II A & $88.77( \pm 6.59)$ & $\begin{array}{l}89.66 \\
(74.48-100)\end{array}$ \\
\hline II B & $89.06( \pm 5.68)$ & $\begin{array}{l}89.36 \\
(74.23-97.87)\end{array}$ \\
\hline
\end{tabular}

Analisis hubungan mekanisme koping dengan skor kecemasan dilakukan dengan uji Mann-Whitney karena hasil uji KolmogorovSmirnov menunjukkan $\mathrm{p}<0.05$, yang artinya data tidak berdistribusi normal. Responden yang menggunakan problem focused coping memiliki median skor kecemasan yang rendah. Pada uji Mann-Whitney didapatkan nilai $\mathrm{p}=0,032$ sehingga disimpulkan terdapat perbedaan skor kecemasan yang signifikan antara responden yang menggunakan mekanisme koping yang berbeda. Analisis korelasi antara skor kecemasan dengan nilai ujian keterampilan medik dilakukan dengan uji korelasi Spearman karena data tidak berdistribusi normal. Hasil uji korelasi
Spearman menunjukkan tidak ada korelasi bermakna antara skor kecemasan dengan nilai ujian keterampilan medik I A dan I B pada responden tahun pertama, maupun antara skor kecemasan dengan nilai ujian, II A dan II B pada responden tahun kedua ( $p>0.05)$. hasil dapat dilihat pada Tabel 5.

Tabel 5. Hubungan antara mekanisme koping dan nilai ujian keterampilan medik dengan skor kecemasan

\begin{tabular}{cc}
\hline Skor & Hasil uji \\
kecemasan & hipotesis \\
Median (min- & \\
maks) & \\
\hline
\end{tabular}



Nilai ujian mahasiswa tahun II $(\mathrm{N}=94)$

\begin{tabular}{ll} 
Ujian IIA & $\mathrm{r}=-0.115$ \\
& $\mathrm{p}=0.270$ \\
& uji korelasi \\
& Spearman \\
& \\
Ujian IIB & $\mathrm{r}=0.076$ \\
& $\mathrm{p}=0.468$ \\
& uji korelasi \\
& Spearman \\
\hline
\end{tabular}

\section{PEMBAHASAN}

Pada penelitian ini median skor kecemasan ujian yang didapatkan adalah 70.00 (31-94). Selain itu ditemukan bahwa median skor kecemasan ujian pada responden perempuan lebih tinggi dibandingkan laki- 
laki. Hal tersebut sejalan dengan penelitian yang dilakukan oleh Hojat et al menemukan bahwa secara signifikan perempuan memiliki skor kecemasan secara umum $(13.8( \pm 3.1)$ vs $12.8( \pm 3.3))$ dan kecemasan ujian $(13.7( \pm 3.5)$ vs $12.7( \pm 3.3)$ lebih tinggi dibandingkan lakilaki ${ }^{23}$.

Pada penelitian yang dilakukan oleh O'Carroll\& Fisher dengan responden mahasiswa kedokteran dan juga menggunakan kuesioner yang sama didapatkan rerata skor kecemasan perempuan lebih tinggi dibandingkan pada laki-laki $(61,88 \pm 12.94$ vs $57.60 \pm 12.40)$ akan tetapi perbedaan keduanya tidak signifikan ${ }^{24}$. Selain itu hasil yang mirip juga ditemukan pada penelitian Blanch et al menyatakan bahwa mahasiswa kedokteran perempuan secara konsisten dilaporkan lebih banyak mengalami kecemasan dibandingkan laki-laki ${ }^{25}$. Penelitian Colbert et al juga menemukan bahwa mahasiswa perempuan lebih cemas dibandingkan laki-laki, dengan tingkat kecemasan tinggi didominasi oleh perempuan $(27 \% \text { vs } 17 \%)^{26}$.

Penelitian yang dilakukan oleh Chandavarkar, Azzam, \& Mathews mengenai gejala kecemasan dan performa pada mahasiswa kedokteran menggunakan kuesioner kecemasan yang berbeda yaitu State-Trait Anxiety Inventory-Trait (STAIT). Penelitian tersebut mendapatkan rerata skor kecemasan pada mahasiswa kedokteran 37.5 ( \pm 9.1$)$. Responden perempuan pada penelitian tersebut menunjukkan skor kecemasan yang juga lebih tinggi dibandingkan dengan laki-laki, namun perbedaan tersebut tidak signifikan (38.3 $( \pm 9.4)$ vs $36.0( \pm 8.1))^{27}$. Kemudian pada penelitian yang dilakukan oleh Simran menunjukkan bahwa tingkat kecemasan ujian mahasiswa kedokteran rata-rata menunjukkan kecemasan yang tinggi. Tingkat kecemasan ujian pada mahasiswa kedokteran terbanyak adalah kecemasan berat (62,72\%) dibandingkan kecemasan sedang hingga ringan $(37,27 \%)$. Pada perempuan juga didapatkan tingkat kecemasan berat yang lebih besar $(73,43 \%)$ dibanding laki-laki $(47,82 \%)^{28}$.

Dalam hal perbedaan kecemasan pada laki-laki dan perempuan, kemungkinan disebabkan karena perempuan cenderung lebih sensitif dibandingkan laki-laki. Terdapat dua penjelasan untuk perbedaan gender dalam kecemasan ujian. Salah satu yang dapat dikaitkan adalah peran sosial yang berbeda antara laki-laki dan perempuan. Hal tersebut dikarenakan perempuan berada di bawah tekanan yang lebih besar daripada laki-laki, sehingga mereka lebih takut gagal dalam situasi ujian. Penjelasan lainnya adalah bahwa laki-laki umumnya lebih defensif daripada perempuan dalam hal mengakui kecemasan yang juga berkaitan dengan maskulinitas sebagai laki-laki ${ }^{29}$.

Selain itu aspek lain yang dapat memengaruhi perbedaan skor kecemasan antara laki-laki dan perempuan diantaranya tingkat kepercayaan diri, persepsi terkait kompetensi serta kemampuan dapat menjadi sumber kecemasan. Mahasiswa perempuan sering merasa tidak yakin dan cenderung lebih menggunakan perasaan dan meremehkan kemampuan yang dimilikinya, dibandingkan dengan mahasiswa laki-laki yang cenderung melebih-lebihkan kemampuannya. Alasan lain yang juga bisa menjadi penyebab kecemasan pada mahasiswa perempuan adalah paparan yang lebih besar terhadap diskriminasi gender $^{25}$.

Penelitian ini juga menunjukkan bahwa skor kecemasan antara mahasiswa tahun pertama dan tahun kedua tidak jauh berbeda. Pada penelitian yang dilakukan oleh Mavis dijelaskan bahwa mahasiswa yang memiliki pengalaman keterampilan klinis lebih banyak cenderung akan mengalami kecemasan dalam ujian keterampilan dikarenakan lebih menyadari hal-hal yang mereka ketahui dan tidak ketahui. Kesadaran akan hal-hal yang tidak diketahui inilah yang meningkatkan kecemasan pada mahasiswa 
yang lebih berpengalaman dibandingkan dengan mahasiswa yang memiliki pengalaman lebih sedikit ${ }^{30}$.

Hubungan yang signifikan antara mekanisme koping dengan skor kecemasan yang ditemukan dalam penelitian ini serupa dengan temuan dalam Rafiki pada mahasiswa keperawatan, Rafiki menemukan bahwa mekanisme koping maladaptif berhubungan signifikan dengan tingkat kecemasan yang lebih berat ( $\mathrm{p}=0,018 \mathrm{pada}$ uji Koefisien Lambda) ${ }^{31}$. Penelitian lain oleh Sumoked pada mahasiswa keperawatan juga menemukan perbedaan signifikan mekanisme koping yang dipilih oleh mahasiswa dengan tingkat kecemasan $(\mathrm{p}<0.01)^{13}$.

Penelitian ini menemukan bahwa responden yang menggunakan problemfocused coping secara signifikan menunjukkan kecemasan yang lebih rendah dibandingkan dengan yang menggunakan emotional-focused coping. Hal ini sejalan dengan yang ditemukan oleh Pradana bahwa problem focused coping berperan secara signfikan terhadap kecemasan. Responden yang memiliki mekanisme koping problem focused coping cenderung memiliki tingkat kecemasan yang rendah ${ }^{32}$.

Namun pada studi lain yang dilakukan oleh Lau, Agustina dan Setiawan didapatkan hasil yang berbeda. Hasil penelitian tersebut menunjukan bahwa proporsi mahasiswa yang menggunakan mekanisme koping emotional focused coping dan problem focused coping hasilnya tidak jauh berbeda. Hal tersebut menunjukkan setiap orang bisa saja menggunakan salah satu mekanisme koping tersebut ataupun keduanya ${ }^{33}$. Menurut Rutter dalam Anam dan Himawan, strategi koping yang paling efektif adalah strategi yang sesuai dengan jenis stres dan situasi ${ }^{34}$.

Mekanisme koping terbentuk dari proses belajar serta mengingat, sehingga mekanisme koping dapat dipelajari saat awal munculnya suatu masalah ataupun stresor ${ }^{13}$. Menurut Santrock dalam Septiyan et al mekanisme koping berhasil jika individu tersebut dapat beradaptasi terhadap perubahan yang terjadi ${ }^{35}$.

Pada penelitian ini tidak terdapat hubungan yang bermakna antara skor kecemasan dengan hasil ujian keterampilan medik. Artinya kecemasan dalam menghadapi ujian keterampilan medik bukan merupakan salah satu faktor yang memberikan kontribusi besar terhadap kelulusan mahasiswa. Hasil penelitian ini mirip dengan penelitian yang dilakukan oleh Amir et al pada mahasiswa kedokteran Universitas Andalas yang menunjukkan tidak ada korelasi antara kecemasan dengan kelulusan OSCE pada mahasiswa $(p>0,05)^{36}$. Brand dan Schoonheim juga menemukan bahwa tidak ada hubungan yang signifikan antara tingkat kecemasan dengan performa mahasiswa ketika ujian ${ }^{10}$.

Kecemasan ujian dapat dialami sebagai kombinasi dari respon fisiologis, emosional, dan perilaku yang bervariasi tergantung pada tiap individu. Kecemasan juga dapat meningkatkan performa dalam situasi tertentu, kecemasan yang dialami saat ujian telah dibuktikan dalam banyak studi berkorelasi negatif dengan performa saat menghadapi ujian. Hal tersebut menyiratkan bahwa maturitas mahasiswa dan / atau peningkatan toleransi terhadap beban kognitif yang tinggi dapat mempengaruhi kekuatan hubungan antara kecemasan ujian dan performa selama OSCE. Dengan demikian, mahasiswa mungkin telah mengembangkan toleransi stres dan / atau mekanisme koping stres yang efektif untuk ujian tersebut. Beberapa strategi yang telah terbukti mengurangi kecemasan terkait OSCE pada mahasiswa ilmu kesehatan termasuk penggunaan teknik pernapasan dalam, OSCE formatif, dan sesi pelatihan ${ }^{37}$.

\section{KESIMPULAN}

Berdasarkan penelitian ini didapatkan jenis mekanisme koping yang paling banyak 
digunakan oleh mahasiswa fakultas kedokteran universitas mataram adalah problem focused coping dan jenis mekanisme koping ini berhubungan dengan skor kecemasan ujian yang lebih rendah. Tidak terdapat hubungan antara skor kecemasan dengan hasil ujian keterampilan medik mahasiswa program studi pendidikan dokter Universitas Mataram.

\section{UCAPAN TERIMA KASIH}

Penulis mengucapkan terima kasih kepada kepala laboratorium keterampilan medik FK UNRAM dr. Isna Kusuma Nintyastuti, Sp.M dan kepada tenaga kependidikan laboratorium keterampilan medik yang telah membantu dalam pengambilan data penelitian ini.

\section{DAFTAR PUSTAKA}

1. Elvira, Sylvia D dan Gitayanti Hadisukanto. Buku Ajar Psikiatri. Badan Penerbit FK UI. Jakarta, 2013 pp. 173-198

2. Maramis, F.W. (2005). Catatan Ilmu Kedokteran Jiwa. Surabaya : Airlangga University Press

3. Rector NA, Bourdeau D, Kitchen K, Massiah LJ. Anxiety Disorders an Information Guide. 2011. $80 \mathrm{p}$.

4. Hamzah F, Mat KC, Bhagat V, Mahyiddin N. Test anxiety and its impact on first year university students and the over view of mind and body intervention to enhance coping skills in facing exams. Res $\mathbf{J}$ Pharm Technol. 2018;11(6):2220-8.

5. Birjandi P. The Impact of Test Anxiety on Test Performance among Iranian EFL Learners. 2010;1(4).

6. Quek TTC, Tam WWS, Tran BX, Zhang M, Zhang Z, Ho CSH, et al. The global prevalence of anxiety among medical students: A meta-analysis. Int J Environ Res Public Health. 2019;16(15).

7. Yasin AS, Dzulkifli MA. Differences in depression, anxiety and stress between lowand high-achieving students. J Sustain Sci Manag. 2011;6(1):169-78.

8. Bandranayke RC, Harden RM. A Practical Guide for Medical Education. 2013;176-81.
9. Gupta P, Dewan P, Singh T. Objective structured clinical examination (OSCE) revisited. Indian Pediatr. 2010;47(11):911-20.

10. Brand HS, Schoonheim-Klein M. Is the OSCE more stressful? Examination anxiety and its consequences in different assessment methods in dental education. Eur $\mathbf{J}$ Dent Educ. 2009;13(3):147-53.

11. Feletti G. ., Neame RLB. Curricular Strategies for Reducing Examination Anxiety Author ( $\mathrm{s}$ ): Grahame I . Feletti and Roderick L . B . Neame Published by: Springer Stable URL: http://www.jstor.org/stable/3446431

Accessed: 28-06-2016 16: 45 UTC. 2016;10(6):675-86.

12. Fidment $\mathrm{S}$. The Objective Structured Clinical Exam (OSCE): A Qualitative Study Exploring the Healthcare Student's Experience. Student Engagem Exp J. 2012;1(1):1-11.

13. Sumoked A. Hubungan Mekanisme Koping Dengan Kecemasan Pada Mahasiswa Semester Iii Program Studi Ilmu Keperawatan Fakultas Kedokteran Yang Akan Mengikuti Praktek Klinik Keperawatan. J Keperawatan. 2019;7(1)

14. Kasi PM, Naqvi HA, Afghan AK, Khawar T, Khan FH, Khan UZ, et al. Coping Styles in Patients with Anxiety and Depression. ISRN Psychiatry. 2012;2012:1-7.

15. Yusuf, A.H F, ,R \& Nihayati H. Buku Ajar Keperawatan Kesehatan Jiwa. Buku Ajar Keperawatan Kesehat Jiwa. 2015;1-366.

16. Ahyar (2010). Konsep Diri dan Mekanisme Koping. Yogyakarta: Pustaka Pelajar.

17. Lazarus RS, Folkman S. STRESS, APPRAISAL, AND COPING. New York: Springer Publishing Company, Inc. 11; 1984.

18. Fares J, Al Tabosh H, Saadeddin Z, El Mouhayyar C, Aridi H. Stress, burnout and coping strategies in preclinical medical students. N Am J Med Sci. 2016;8(2):75-81.

19. Cha ES, Kim KH, Erlen JA. Translation of scales in cross-cultural research: Issues and techniques. J Adv Nurs. 2007;58(4):386-95.

20. Carver CS. You want to measure coping but your protocol's too long: Consider the brief COPE. Int J Behav Med. 1997;4(1):92-100.

21. Pratiwi I. Hubungan Coping Strategy dan Self-Efficacy Dengan Kecemasan Pada Karyawan Usia Produktif di Bandung Universitas Pendidikan Indonesia perpustakaan.upi.edu. 2016.

22. Akasyah W. Determinan Ketahanan Psikologis Remaja Korban Bullying dengan Pendekatan Model Adaptasi Stres Stuart. 2018. 188 p.

23. Hojat M, Glaser $\mathrm{K}, \mathrm{Xu} \mathrm{G}$, Veloski JJ, Christian EB. Gender comparisons of medical 
students' psychosocial profiles. Med Educ. 1999;33(5):342-9.

24. O’Carroll PJ, Fisher P. Metacognitions, worry and attentional control in predicting OSCE performance test anxiety. Med Educ. 2013;47(6):562-8.

25. Blanch DC, Hall JA, Roter DL, Frankel RM. Medical student gender and issues of confidence. Patient Educ Couns. 2008;72(3):374-81.

26. Colbert-Getz JM, Fleishman C, Jung J, Shilkofski N. How do gender and anxiety affect students' self-assessment and actual performance on a high-stakes clinical skills examination? Acad Med. 2013;88(1):44-8.

27. Chandavarkar U, Azzam A, Mathews CA. Anxiety symptoms and perceived performance in medical students Uma. Int J Curr Adv Res. 2015;4(11):485-7.

28. Simran G, Sangeeta N, Lily W. Evaluation of examination anxiety status and its associated factors among first professional medical (MBBS) students. J Interdiscip Multidiscip Res. 2015;2(8):1-11.

29. Núñez-Peña MI, Suárez-Pellicioni M, Bono R. Gender Differences in Test Anxiety and Their Impact on Higher Education Students' Academic Achievement. Procedia - Soc Behav Sci [Internet]. 2016;228(July):154-60. Available from: http://dx.doi.org/10.1016/j.sbspro.2016.07.023

30. Mavis B. Self-Efficacy and OSCE Performance among Second Year Medical Students. Adv Heal Sci Educ. 2001;6(2):93102.

31. Rafiki DM. Hubungan tingkat kecemasan dengan mekanisme koping menghadapi objective structured clinical examination (OSCE) mahasiswa semester II STIKES Jenderal Achmad Yani Yogyakarta. Available from: http://repository.unjaya.ac.id/2203/

32. Pradana IGNA, Susilawati LKPA. Peran Problem Focused Coping dan Dukungan Sosial Teman Sebaya terhadap Kecemasan Remaja SMA yang Akan Menempuh Ujian Nasional. Psikol Udayana. 2019;000(2010):111.

33. Lau DK, Agustina V, Setiawan H. Gambaran tingkat ansietas dan mekanisme koping pada mahasiswa keperawatan dalam menghadapi ujian praktek laboratorium. J Keperawatan Jiwa. 2019;7(2):215.

34. Anam C, Himawan AT. Peran EmotionFocused Coping Terhadap Kecenderungan Post-Traumatic Stress Disorder Para Karyawan Yang Menyaksikan Peledakan Bom Di Depan Kedutaan Besar Australia Di Jakarta Tahun 2004. Humanit Indones Psychol J.
2004;2(2):112-8.

35. Septiyan A, Erwin, Sabrian F. Hubungan Mekanisme Koping Terhadap Kinerja Perawat Pelaksana Di ruang Rawat Inap. 2011;(2008):1-9.

36. Putri Amir D, Iryani D, Isrona L. Hubungan Tingkat Kecemasan dalam Menghadapi Objective Structured Clinical Examination (OSCE) dengan Kelulusan OSCE pada Mahasiswa Fakultas Kedokteran Universitas Andalas. J Kesehat Andalas. 2016;5(1):13944.

37. Martin Randy D, Nazirudin Z. Systematic review of student anxiety and performance during objective structured clinical examinations. Currents in Pharmacy Teaching and Learning . 2020;12(12): 1491-1497. 